\title{
Myxobolus marajoensis sp. n. (Myxosporea: Myxobolidae), parasite of the freshwater catfish Rhamdia quelen from the Brazilian Amazon region
}

Myxobolus marajoensis sp. n. (Myxosporea: Myxobolidae), parasita do bagre de água doce Rhamdia quelen da região da Amazônia brasileira

\author{
Jacqueline Abrunhosa ${ }^{1,2}$; José Ledamir Sindeaux-Neto ${ }^{1,2}$; Ândrea Kely dos Santos ${ }^{3}$; Igor Hamoy ${ }^{4}$; Edilson Matos ${ }^{1,2 *}$ \\ ${ }^{1}$ Programa de Pós-graduação em Biologia de Agentes Infecciosos e Parasitários - BAIP, Universidade Federal do Pará - UFPA, Belém, \\ PA, Brasil \\ ${ }^{2}$ Laboratório de Pesquisa Carlos Azevedo, Universidade Federal Rural da Amazônia - UFRA, Belém, PA, Brasil \\ ${ }^{3}$ Laboratório de Genética Humana e Médica, Universidade Federal do Pará - UFPA, Belém, PA, Brasil \\ ${ }^{4}$ Laboratório de Genética Aplicada, Universidade Federal Rural da Amazônia - UFRA, Belém, PA, Brasil
}

Received August 25, 2017

Accepted October 24, 2017

\begin{abstract}
This study provides morphological and molecular data of a new parasite species found in the muscle layer of the intestinal tract of the South American silver catfish, Rhamdia quelen from Marajó Island region (Pará State, Brazil), an important fishery resource with recognized potential for fish farming. The morphology of these parasites was reanalyzed and phylogenetic analyses were run on their $18 \mathrm{~S} \mathrm{rDNA}$ gene sequences. The spores were morphologically distinct from those of other Myxobolus species described previously. The obtained partial sequence of the $18 \mathrm{~S} \mathrm{rDNA}$ gene sequences of the new species were compared to those of 24 other Myxobolus and Henneguya species available in GenBank. The results of morphological and molecular analyses indicated clearly the existence of a new species, Myxobolus marajoensis sp. $\mathrm{n}$.

Keywords: Amazonia, fish, Siluriform, Myxozoa, intestine, Marajó Island.

\section{Resumo}

Este estudo fornece dados morfológicos e moleculares de um novo parasita encontrado na parede intestinal do jandiá, Rhamdia quelen coletado na regiáo da ilha do Marajó (Estado do Pará, Brasil), um importante recurso pesqueiro com potencial para aquicultura. Foram realizadas comparaçóes morfológicas deste parasita e análises filogenéticas da regiáo do gene $18 \mathrm{~S}$ rDNA sequenciada. Os esporos foram morfologicamente distintos das espécies de outros Myxobolus descritos anteriormente. A sequência parcial obtida do gene $18 \mathrm{~S}$ rDNA da nova espécie foi comparada com outras 24 espécies de Myxobolus e Henneguya retiradas do GenBank. Os resultados de análises morfológica e molecular indicaram claramente a existência de uma nova espécie, Myxobolus marajoensis sp. n.
\end{abstract}

Palavras-chave: Amazônia, peixe, Siluriforme, Myxozoa, intestino, Ilha do Marajó.

\section{Introduction}

Myxobolus Bütschli, 1882 is an important microparasite genus, with approximately 856 species. Some of these species have a considerable impact on fishery productivity by provoking diseases in both the natural environment and the farmed fish (GILBERT \& GRANATH, 2001; EIRAS et al., 2005, 2014; LOM \& DIKOVÁ, 2006).

\footnotetext{
*Corresponding author: Edilson Matos. Laboratório de Pesquisa Carlos Azevedo, Universidade Federal Rural da Amazônia - UFRA, Avenida Presidente Tancredo Neves, 2501, Montese, CEP 66077-901, Belém, PA, Brasil. e-mail: edilson.matos9@gmail.com
}

In the catfish (Siluriformes), these parasites have been found infecting a variety of organs, such as the gills of the bandit corydoras, Corydoras melini Lönnberg and Rendahl, 1930 (MATHEWS et al., 2016) and the jau, Zungaro jahu Ihering, 1898 (ADRIANO et al., 2009), the intestine of the Amur catfish Silurus asotus Linnaeus, 1758 (LIU et al., 2016) and the Philippine catfish Clarias batrachus Linnaeus, 1758 (NARASIMHAMURTI \& KALAVATI, 1986), the intestine and gills of the European chub, Leuciscus cephalus Linnaeus, 1758 (MOLNÁR et al., 2007) and the spleen of the striped catfish, Pangasianodon hypophthalmus Sauvage, 1878 (BASKA et al., 2009). 
In Brazil, the South American silver catfish Rhamdia quelen Quoy and Gaimard, 1824 is an important fishery resource, as well as being a potentially valuable species for fish farming in southern Brazil (BALDISSEROTO \& RADUNZ, 2004; BRASIL, 2011). Despite being exploited widely as a source of human food, few studies are available on the parasitism of this species, except for Matos et al. (2005), who described the myxosporean Henneguya rhamdia, found in the gills of this catfish. More recently, Abrunhosa et al. (2016) reported on the occurrence of cysts caused by Myxobolus, which caused inflammatory processes in the intestine of the $R$. quelen.

This study aims to describe a new myxosporean species found in the intestinal tissue samples of the $R$. quelen based on the morphological features and in the data of the partial sequence of the DNA of the $18 \mathrm{~S}$ small ribosomal subunit in order, to verify the phylogenetic position.

\section{Materials and Methods}

\section{Fish sampling}

Samples were obtained from 20 adult specimens (body length $15-23 \mathrm{~cm}$ ) of $R$. quelen captured using nylon gill nets on the Paracauari River, in the municipality of Salvaterra $\left(00^{\circ} 45^{\prime} \mathrm{S}\right.$; $\left.48^{\circ} 31^{\prime} \mathrm{W}\right)$ on Marajó Island (Pará State), northern Brazil, in the Amazon region. The specimens were anesthetized with $50 \mathrm{mg} / \mathrm{L}$ of tricaine methanesulfonate (MS222 SIGMA) for transportation to the laboratory, where they were maintained in aquaria until necropsy. Before dissection, the fish were anesthetized until death, according to the rules of the UFRA ethics committee for animal experimentation (CEUA: 013/2014).

\section{Sample preparation and histological analysis}

The organs were examined under a ZEISS stereomicroscope. Once detected in the intestinal tract of the hosts, the cysts were extracted carefully for the preparation of slides and analyzed by light microscopy (Olympus CX41).

From fresh examination, the cysts were removed from the muscular layer of the intestine using tweezers and placed on glass slides covered with cover slips. The spores were released from the cysts smeared on the slides with a few drops of distilled water. Fresh plasmodia with mature spores were examined morphologically and morphometrically by light microscopy and the photomicrographs were obtained with DFC310 FX camera (Leica) under light microscopy conjugated with DIC (DM2500, 40 objective, Leica). The cysts were photographed under a Zeiss Primo Star stereomicroscope equipped with a Zeiss AxioCam ERc 5s camera and the AxioVision 5.1 software. For the histological procedure, small fragments of the parasitized tissue extracted from the intestinal were then fixed in Davidson's solution for $24 \mathrm{~h}$ before being processed and stained using the Hematoxylin and Eosin technique (LUNA, 1968).

\section{Molecular characterization and phylogenetic analysis}

For the molecular and phylogenetic analyses, the cysts were removed from the intestine and preserved in $80 \%$ alcohol. The analyses included samples of the intestines of $10 \mathrm{R}$. quelen specimens infected by Myxobolus held by the Carlos Azevedo Research Laboratory at UFRA. These specimens were collected from the Paracauari River in the municipality of Salvaterra $\left(00^{\circ} 45^{\prime} \mathrm{S}\right.$; $\left.48^{\circ} 31^{\prime} \mathrm{W}\right)$, Marajó Island, in the Brazilian Amazon region, between March and September 2016.

The DNA was extracted using a PureLink ${ }^{\circledR}$ Genomic DNA Mini kit (Invitrogen), following the maker's protocol. The DNA content was determined using a NanoDrop 2000 spectrophotometer (Thermo Scientific) at $260 \mathrm{~nm}$ and then diluted to $5 \mathrm{ng} / \mu \mathrm{L}$. The MC5 (forward) 5'-CCTGAGAAACGGCTACCACATCCA-3' and MC3 (reverse) 5'-GATTAGCCTGACAGATCACTCCACGA-3 primers (MOLNÁR, 2002) were used to amplify the $18 \mathrm{~S}$ (SSU rDNA) gene by Polymerase Chain Reaction (PCR) in the SimpliAmpli Thermal Cycler (Applied Biosystems).

The final volume of the PCR was $25 \mu \mathrm{L}$, which contained approximately 5-10 $\mathrm{ng}$ of the DNA template, $2 \mathrm{mM} \mathrm{MgCl}$, $4 \mathrm{mM}$ of dNTP mix (Invitrogen), 5 pmol of each primer and 1.2 units of Taq DNA polymerase (Invitrogen ${ }^{\circledR}$ ). The amplification protocol consisted of denaturation at $95^{\circ} \mathrm{C}$ for $1 \mathrm{~min}$, followed by for 35 cycles $66^{\circ} \mathrm{C}$ for $1 \mathrm{~min}$ followed by $72{ }^{\circ} \mathrm{C}$ for $2 \mathrm{~min}$ and then by $5 \mathrm{~min}$ at $95^{\circ} \mathrm{C}$, followed by a final extension at $72{ }^{\circ} \mathrm{C}$ for $30 \mathrm{~min}$.

Aliquots $(3 \mu \mathrm{L})$ of the PCR products were visualized with Sybr ${ }^{\circledR}$ safe DNA gel stain (Invitrogen) after electrophoresis on $1 \%$ agarose gel, and purified using GFX PCR DNA and a Gel Purification kit (GE Healthcare), according to the manufacturer's instructions. The samples were sequenced using an ABI 3130 automatic DNA analyzer (Applied Biosystems) with BigDye ${ }^{\circledR}$ (Applied Biosystems) Terminator v3.1, following the manufacturer's specifications. The MC5 and MC3 primers used to obtain the amplicons were also used in the sequencing process. The nucleotide sequences obtained here were edited and aligned using the BioEdit software (HALL, 2007).

The partial sequence of the 18S rDNA gene of the Myxobolus specimens obtained from the intestinal tissue of $R$. quelen was aligned using the BioEdit software (HALL, 2007) for comparisons with the 24 sequences of closely related species of Myxobolus and Henneguya (obtained from both freshwater and marine fish) available in blast search and GenBank sequences. The outgroup was Zschokkella nova, GenBank sequences DQ377688.

Phylogenetic relationships were determined through Bayesian Inference (BI), using Markov Chain Monte Carlo (MCMC) tree searches in MrBayes 3.1.2 (RONQUIST \& HUELSENBECK, 2003). The most appropriate evolutionary model was determined using jModelTest 2.0.2 (DARRIBA et al., 2012), based on the Akaike Information Criterion (AIC). We performed two parallel runs of four simultaneous MCMC searches of 5 million generations each, sampling one tree every 500 generations, and discarding the results of the first 1000 trees as burn-in. The remaining trees were used by MrBayes to estimate the posterior probability of each node in the phylogenetic reconstruction. Tracer v1.4.1 (RAMBAUT et al., 2008) was used to check the stationarity of all 
the parameters sampled by the chains, as indicated by jModelTest 2.0.2 (DARRIBA et al., 2012). Genetic distances ( $p$ ) in relation to other Myxobolus species were determined using PAUP $4.0 \mathrm{~b}$ (SWOFFORD, 1998).

\section{Results}

\section{Description of Myxobolus marajoensis sp. $n$.}

Type host: Rhamdia quelen Quoy and Gaimard, 1824 Type locality: Paracauri River, municipality of Salvaterra ( $00^{\circ} 45^{\prime}$ 'S, $\left.48^{\circ} 31^{\prime} \mathrm{W}\right)$ on Marajó Island, Pará State, Brazil.

Site of tissue development: muscular layer of the intestine. Prevalence: 20\% (4/20).
Representative sequence: The $18 \mathrm{~S} \mathrm{rDNA}$ sequence of M. marajoensis sp. n. (Figures 1c and d) is deposited in GenBank under accession number KX857727.

Etymology: The specific epithet marajoensis refers to the collecting locality, Marajó Island, in Brazil.

\section{Description}

Cyst: The cysts were found ellipsoidal to oval-shaped showing a whitish colour and averaging $345 \mu \mathrm{m}$ (213-408) in length and $195 \mu \mathrm{m}(122-245)$ in width (Figure 1a).

Histology: In histological sections, cysts were found in the intestinal layer between luminar mucosa and the serosal layer (Figure 1b).
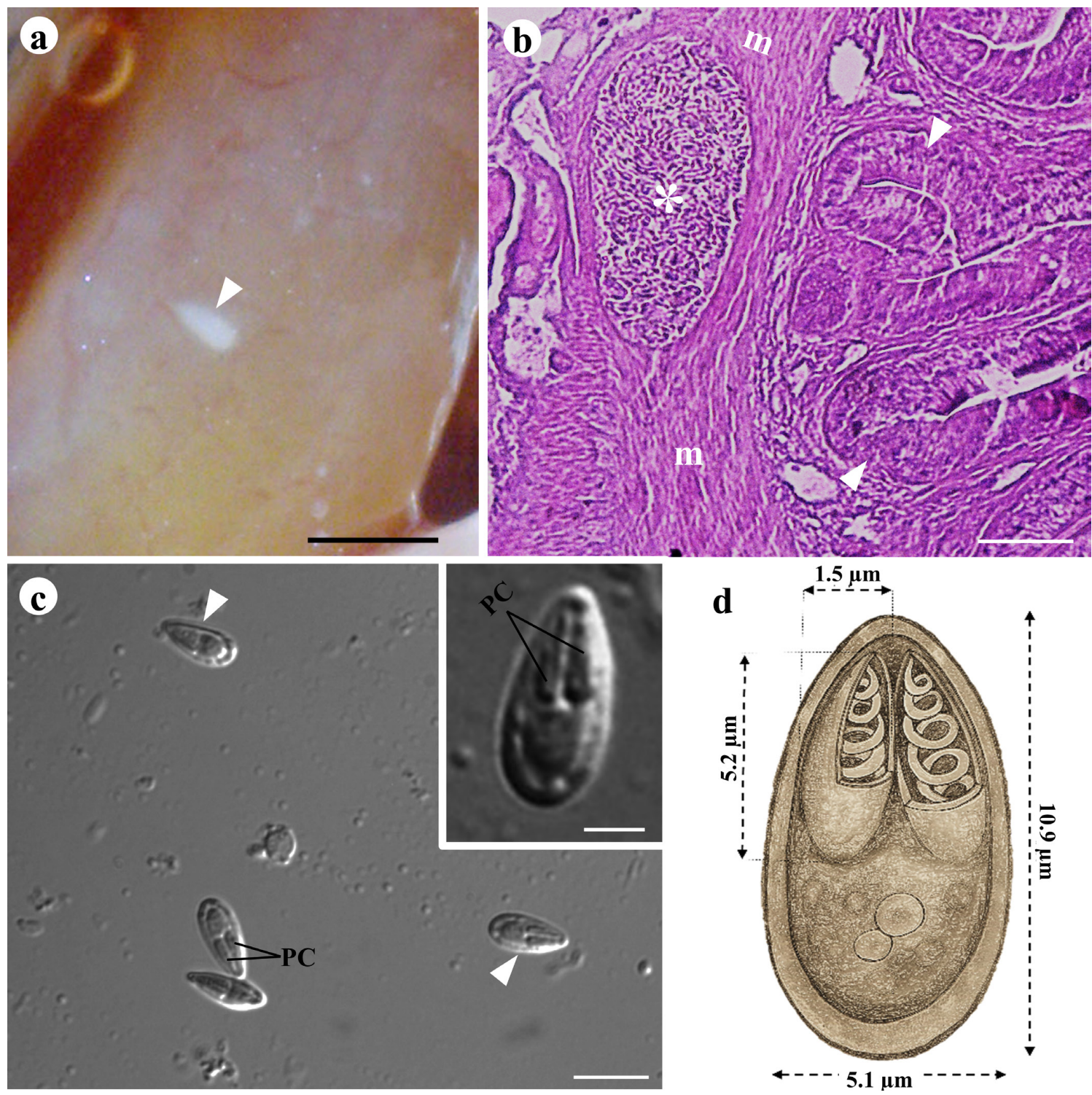

Figure 1. Myxobolus marajoensis sp. n. of Rhamdia quelen. (a) Intestine with a cyst (arrow head); Scale bar = $2000 \mu \mathrm{m}$; (b) Histological section of the intestine stained with Hematoxylin and Eosin, showing the cyst $\left(^{*}\right)$ in the muscle layer $(\mathrm{m})$, detail of the intestinal mucosa (arrow head); Scale Bar $=75 \mu \mathrm{m}$; (c) Spores (arrow head) with polar capsules (PC); Scale bar $=15 \mu \mathrm{m}$; Inset; Detail of fresh spores, with polar capsules (PC) under Differential Interference Contrast (DIC); Scale bar $=3 \mu \mathrm{m}$; (d) Schematic drawing of a spore, found in the intestine; Spore in valvular view, showing its internal organization. 
Mature spores: Mature pyriform spores (Figure 1c) were observed with a mean length of $10.9 \mu \mathrm{m}(10.0-11.6)$ and mean width of $5.1 \mu \mathrm{m}$ (4.2-5.4). Each spore bears two polar capsules of equal size, $5.3 \pm 0.6 \mu \mathrm{m}$ long and $1.6 \pm 0.36 \mathrm{~m}$ wide (Table 1 ).

Type material: Slides containing spores were obtained from the muscle layer of the intestine, processed using the paraffin technique, stained with Gutierrez (Figure 1b), and mounted by the low viscosity method. These specimens were deposited in the International Protozoan Type Specimen Collection at the Brazilian National Institute of Amazonian Research (INPA) in Manaus, Amazonas, Brazil (catalog number: INPA 026).

\section{Molecular data}

Based on the alignment of $929 \mathrm{bps}$, the $18 \mathrm{~S}$ rDNA sequence of Myxobolus marajoensis sp. n. was distinct from all the other Myxobolus sequences, obtained from other siluriform catfish, and from all other myxozoan species. The pairwise $p$ distances recorded in relation to the other Myxobolus species that parasitize siluriforms were all relatively high, with the lowest value (13.0\%) being recorded for $M$. flavus, reinforcing the existence of a new species (Table 2).

The phylogenetic tree is formed by two clades, $A$ and $B$, with both clades including two subclades (A1 and A2, and B1 and B2). Subclade A1 encompasses the Myxobolus and Henneguya species found in freshwater siluriforms and characiforms, while subclade A2 includes the Myxobolus species that infect marine mugiliforms. Subclade B1 included species that parasitize siluriform and cypriniform hosts, while subclade B2 contained parasites of siluriform and characiform hosts ( $M$. plasmodialis and $M$. aureus), which were allocated to different branches (Figure 2).
The phylogenetic analyses indicated that the Myxobolus species of clade A are paraphyletic, grouping with four Henneguya species, $H$. eirasi, $H$. maculosos, $H$. visibilis and $H$. pellucida. Myxobolus marajoensis sp. $\mathrm{n}$. forms a subclade isolated from the other taxa of clade A. Phylogenetically, Myxobolus marajoensis sp. n. is associated with subclade A1, and was placed closest to M. flavus in the Bayesian inference (Figure 2).

\section{Discussion}

In the present study, the parasites were investigated in more detail, based on the analysis of their structural and morphometric characteristics (Figures 1c and d), as well as phylogenetic criteria (Figure 2), and the sum of the evidence indicated conclusively the existence of a new species, denominated $M$. marajoensis sp. n.

The morphology of this species is similar to that of $M$. miyarii (LIU et al., 2016) and M. cunhai (PENIDO, 1927), given the pyriform shape of the spores, which are distinct from the ovoid spores of $M$. pangasii (MOLNÁR et al., 2006), the elliptical spores of $M$. hakyi Baska et al. (2009) and M. gayerae Molnár et al. (2007), and the spherical spores of $M$. bivacuolatus (NARASIMHAMURTI \& KALAVATI, 1986) (Table 1)

The spores of Myxobolus marajoensis sp. n. (Figures 1c and d) are smaller in size than those of most other Myxobolus species found in catfish, except for $M$. cunhai, which infects the catfish Pimelodus clarias maculatus Lacepède, 1803 (PENIDO, 1927), and $M$. bivacuolatus, which have spores similar in size to those of Myxobolus marajoensis sp. n. (Table 1). Even so, these two species can be differentiated on the basis of the relative size of the polar capsules, with two polar capsules of equal size in Myxobolus marajoensis sp. n., whereas in $M$. cunhai, these structures are extremely elongated and unequal in size.

Table 1. Comparison of the parameters (mean measurements in $\mu \mathrm{m}$ ) of the spores of Myxobolus spp. described for different freshwater and marine catfish species (Siluriformes).

\begin{tabular}{|c|c|c|c|c|c|c|c|c|c|}
\hline Myxobolus species & Hosts & $\begin{array}{l}\text { Infection } \\
\text { site }\end{array}$ & $\begin{array}{l}\text { Spore } \\
\text { shape }\end{array}$ & SL & SW & PCL & PCW & $\begin{array}{c}\text { Size of } \\
\text { the polar } \\
\text { capsules }\end{array}$ & Country \\
\hline M. hakyi (BASKA et al., 2009) & Pangasius hypohthalmus & Epiderm & Elipsoidal & 15.9 & 6.6 & 6.3 & 2.3 & Equal & Thailand \\
\hline M. pangasii (MOLNÁR et al., 2006) & Pangasius hypophthalmus & Spleen & Ovoid & 14.3 & 7.03 & 6.4 & 1.7 & Equal & Malaysia \\
\hline M. miyarii (LIU et al., 2016) & Silurus asotus & Intestine & Pyriform & 13.3 & 6.6 & 6.5 & 1.9 & Equal & Japan \\
\hline M. cunhai (PENIDO, 1927) & Pimelodus clarias & Intestine & Pyriform & 10.0 & 5.0 & - & - & Unequal & Brazil \\
\hline $\begin{array}{l}\text { M. bivacuolatus (NARASIMHAMURTI } \\
\text { \& KALAVATI, 1986) }\end{array}$ & Clarias batrachus & Intestine & Spherical & 9.0 & - & 4.2 & 3.0 & Equal & India \\
\hline M. marajoensis sp. n. (Present study) & Rhamdia quelen & Intestine & Pyriform & 10.9 & 5.1 & 5.2 & 1.5 & Equal & Brazil \\
\hline
\end{tabular}

SL: spore length, SW: spore width, PCL: polar capsule length, PCW: polar capsule width.

Table 2. P distance of some freshwater species of Myxobolus described in Siluriformes showing Genbank accessions after species name.

\begin{tabular}{|c|c|c|c|c|c|c|c|}
\hline & & 1 & 2 & 3 & 4 & 5 & 6 \\
\hline 1 & Myxobolus marajoensis (KX857727) & & & & & & \\
\hline 2 & Myxobolus flavus (KF296346) & 0.130 & & & & & \\
\hline 3 & Myxobolus hakyi (FJ816269) & 0.135 & 0.115 & & & & \\
\hline 4 & Myxobolus miyarii (KT001495) & 0.142 & 0.130 & 0.135 & & & \\
\hline 5 & Myxobolus sp.1 (KP990667) & 0.233 & 0.216 & 0.221 & 0.233 & & \\
\hline 6 & Myxobolus gayerae (DQ439809) & 0.241 & 0.243 & 0.255 & 0.248 & 0.241 & \\
\hline 7 & Myxobolus muelleri (DQ439806) & 0.243 & 0.115 & 0.245 & 0.235 & 0.250 & 0.075 \\
\hline
\end{tabular}




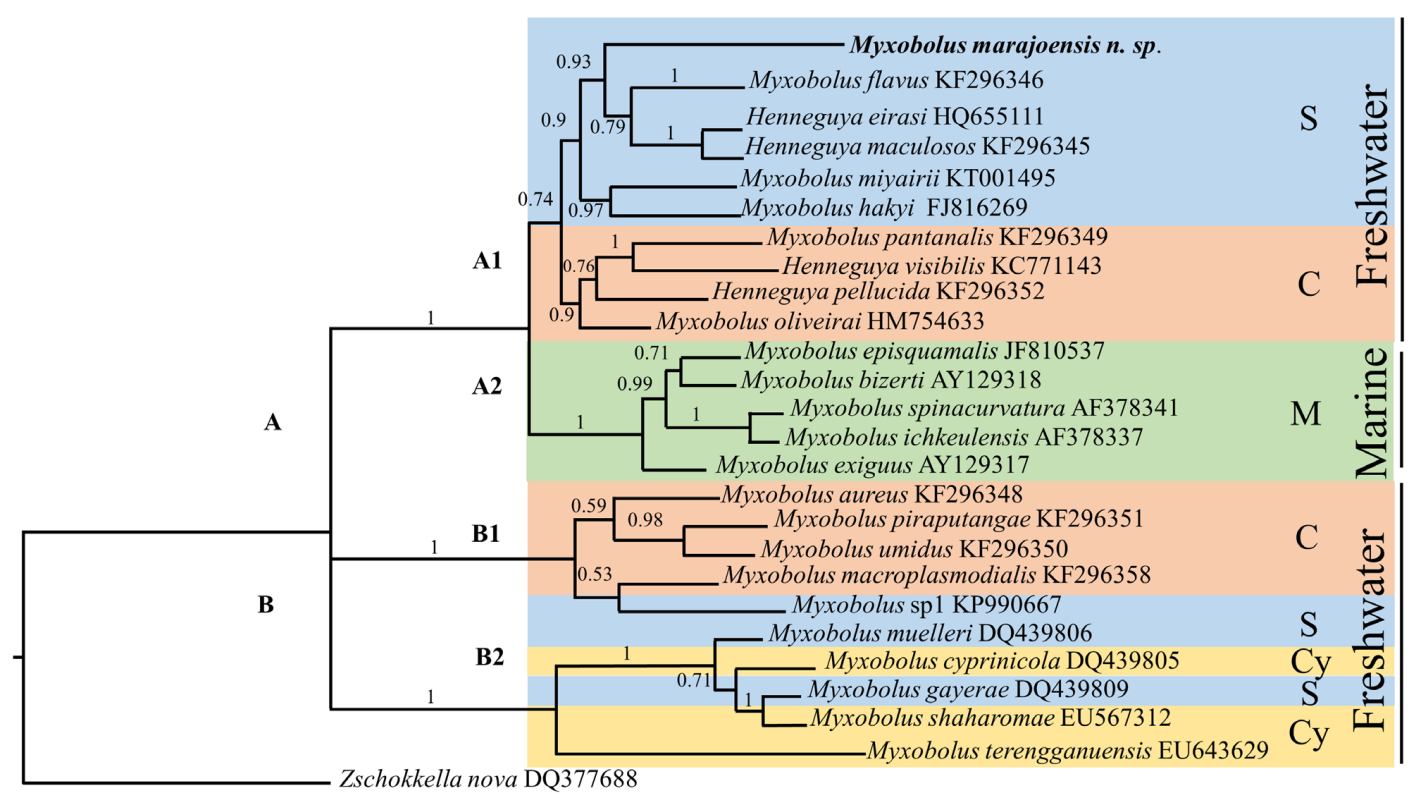

$\underline{0.08}$

Figure 2. Phylogenetic tree of Myxobolus marajoensis sp. $\mathrm{n}$. inferred by Bayesian analysis using a SSU rDNA data set. The values associated with each branch are their posterior probabilities. The species names are followed by their GenBank accession numbers. $S=$ Siluriformes; $\mathrm{C}=$ Characiformes; $\mathrm{M}=$ Mugiliformes; $\mathrm{Cy}=$ Cypriniformes.

In comparison with the Myxobolus species found in the intestinal tracts of other catfish species, Myxobolus marajoensis sp. n. is closest in size to $M$. cunhai, which infects the catfish $P$. clarias maculatus (PENIDO, 1927), M. bivacuolatus and $M$. pangasii, found in Pangasius hypophthalmus (MOLNÁR et al., 2006; BASKA et al., 2009), and M. miyarii, a parasite of S. asotus (LIU et al., 2016) (Table 1). Myxobolus marajoensis sp. $\mathrm{n}$. is smaller than the Myxobolus species found infecting cyprinid hosts, such as $M$. gayerae in L. cephalus (MOLNÁR et al., 2007), M. nodulointestinalis in Barbus sharpeyi Gunther, 1874 (MASOUMIAN et al., 1996), and $M$. cyprinicola in Cyprinus carpio Linnaeus, 1758 (MOLNÁR, 2002).

The phylogenetic analysis, based on comparisons with the 18S rDNA gene of 24 Myxobolus and Henneguya species obtained from GenBank, provided clear evidence of the existence of a distinct new species. A number of other Myxobolus species found in siluriforms have been described based on the analysis of the $18 \mathrm{~S}$ rDNA gene, including $M$. myarii, found in the $S$. asotus by Liu et al. (2016). Using this gene, Baska et al. (2009) confirmed the presence of $M$. hakyi in the epidermis of the P. hypophthalmus, while Molnár et al. (2006) found $M$. pangasii infecting its spleen.

The phylogenetic relatedness of the Myxobolus and Henneguya species reflects a tendency for the formation of parasite clades related closely to their host species (CARRIERO et al., 2013), indicating coevolutionary relationships between the ancestral parasites and their hosts (BROUGHTON et al., 2013). In fact, the cladogram (Figure 2) reflects a grouping associated more closely with the hosts than the morphological or biogeographic characteristics of the parasites themselves.

Fish parasitized by the myxozoan species tend to form groups based on the type of environment (freshwater or marine) and taxon (FIALA, 2006; FERGUSON et al., 2008; ADRIANO et al., 2012;
CARRIERO et al., 2013; MOREIRA et al., 2014). The lowest $p$ distance recorded between $M$. marajoensis sp. n. and a congener was $13.0 \%$, in the case of $M$. flavus (Table 2); increasing progressively in relation to the other Myxobolus clades that together with the morphological data presented here, support the classification of the new myxosporidean species. New microparasite species are described regularly in the Amazon region, based on histological and molecular evidence, such as the description of the morphological features of M. niger, found in the gill rake of the bandit corydoras (C. melini) by Mathews et al. (2016). Rocha et al. (2016) provide molecular data on Kudoa Meglitsch, 1947 found infecting the blue discus, Symphysodon aequifasciatus Pellegrin, 1904. Adriano et al. (2009) described $M$. cordeiroi from the gills of the siluriform $Z$. jahu, based on a phylogenetic topology similar to that described in the present study, with a fundamental division between the freshwater and marine species of Myxobolus, indicating a systematic relationship with the type of habitat occupied by the host.

The results of the present study provide important insights into the myxosporidean infections found in $R$. quelen, which may cause significant tissue damage (MARTINS et al., 1999; ADRIANO et al., 2005a, b, 2006; FEIST \& LONGSHAW, 2006) or even death (MARTINS et al., 1999; FEIST \& LONGSHAW, 2006). A better understanding of this freshwater microparasite fauna will be essential for the prevention and control of diseases in both wild and farmed stocks. This will be important not only to guarantee the health of stocks, but also the quality of the end product for human consumption.

Based on the morphological description and the molecular and phylogenetic analyses (18S rDNA sequences) comparing 24 sequences of Myxobolus and Henneguya species that parasitize freshwater and marine siluriforms, cypriniforms, mugiliforms, and characiforms, 
the results of the present study provide conclusive evidence of the existence of a new species, Myxobolus marajoensis sp. n., from the Brazilian Amazon region.

\section{References}

Abrunhosa JP, Silva MVO, Sindeaux J No, Santos PFS, Matos PS, Sanches OC, et al. Myxozoan infection in the muscle layer of the intestine of Rhamdia quelen from the Amazon River Basin, Brazil. Cienc Rural 2016; 46(11): 2024-2028. http://dx.doi.org/10.1590/0103-8478cr20151652.

Adriano EA, Arana S, Alves AL, Silva MRM, Ceccarelli PS, Henrique-Silva F, et al. Myxobolus cordeiroi n. sp., a parasite of Zungaro jahu (Siluriformes: Pimelodidae) from Brazilian Pantanal: morphology, phylogeny and histopathology. Vet Parasitol 2009; 162(3-4): 221-229. PMid:19372007. http://dx.doi.org/10.1016/j.vetpar.2009.03.030.

Adriano EA, Arana S, Cordeiro NS. Histophatology and ultrastructure of Henneguya caudalongula sp. n. infecting Prochilodus lineatus (Pisces: Prochilodontidae) cultivated in the state of São Paulo, Brazil. Mem Inst Oswaldo Cruz 2005a; 100(2): 177-181. PMid:16021305. http://dx.doi. org/10.1590/S0074-02762005000200011.

Adriano EA, Arana S, Cordeiro NS. An ultrastructural and histopathological study of Henneguya pellucida n. sp. (Myxosporea: Myxobolidae) infecting Piaractus mesopotamicus (Characidae) cultivated in Brazil. Parasite 2005b; 12(3): 221-227. PMid:16218209. http://dx.doi.org/10.1051/ parasite/2005123221.

Adriano EA, Arana S, Cordeiro NS. Myxobolus cuneus n. sp. (Myxosporea) infecting the connective tissue of Piaractus mesopotamicus (Pisces: Characidae) in Brazil: histopathology and ultrastructure. Parasite 2006; 13(2): $137-$ 142. PMid:16800122. http://dx.doi.org/10.1051/parasite/2006132137.

Adriano EA, Carriero MM, Maia AAM, Silva MRM, Naldoni J, Ceccarelli PS, et al. Phylogenetic and host-parasite relationship analysis of Henneguya multiplasmodialis $\mathrm{n}$. sp. infecting Pseudoplatystoma spp. in Brazilian Pantanal wetland. Vet Parasitol 2012; 185(2-4): 110-120. PMid:22051071. http://dx.doi.org/10.1016/j.vetpar.2011.10.008.

Baldisseroto B, Radunz J No. Criação de Jundiá. Santa Maria: Ed. UFSM; 2004. 232 p.

Baska F, Voronin VN, Eszterbauer E, Müller L, Marton S, Molnár K. Occurrence of two myxosporean species, Myxobolus hakyi sp. n. and Hoferellus pulvinatus sp. n., in Pangasianodon hypophthalmus fry imported from Thailand to Europe as ornamental fish. Parasitol Res 2009; 105(5): 1391-1398. PMid:19629523. http://dx.doi.org/10.1007/s00436-0091567-x.

Brasil. Ministério da Pesca e Aquicultura. Boletim estatístico da pesca e aquicultura 2011. Brasília: MPA; 2011.60 p.

Broughton RE, Betancur RR, Li C, Arratia G, Orti G. Multi-locus phylogenetic analysis reveals the pattern and tempo of bony fish evolution. PLoS Curr 2013; 5: 5. PMid:23788273.

Carriero MM, Adriano EA, Silva MR, Ceccarelli PS, Maia AA. Molecular phylogeny of the Myxobolus and Henneguya genera with several new South American species. PLoS One 2013; 8(9): e73713. PMid:24040037. http:// dx.doi.org/10.1371/journal.pone.0073713.

Darriba D, Taboada GL, Doallo R, Posada D. jModelTest 2: more models, new heuristics and parallel computing. Nat Methods 2012; 9(8): 772. PMid:22847109. http://dx.doi.org/10.1038/nmeth.2109.
Eiras JC, Molnár K, Lu YS. Synopsis of the species of Myxobolus Bütschli, 1882 (Myxozoa: Myxosporea: MyxoBolidae). Syst Parasitol 2005; 61(1): 1-46. PMid:15928990. http://dx.doi.org/10.1007/s11230-004-6343-9.

Eiras JC, Zhang J, Molnár K. Synopsis of the species of Myxobolus Butschli, 1882 (Myxozoa: Myxosporea, Myxobolidae) described between 2005 and 2013. Syst Parasitol2014; 88(1): 11-36. PMid:24711110. http://dx.doi. org/10.1007/s11230-014-9484-5.

Feist SW, Longshaw M. Phylum Myxozoa. In: Woo PTK, editor. Fish diseases and disorders: protozoan and metazoan infections. vol. 1. 2nd ed. Oxfordshire: CAB International; 2006. p. 230-296.

Ferguson JA, Atkinson SD, Whipps CM, Kent ML. Molecular and morphological analysis of Myxobolus spp. of salmonid fishes with the description of a new Myxobolus species. J Parasitol 2008; 94(6): 13221334. PMid:19127969. http://dx.doi.org/10.1645/GE-1606.1.

Fiala I. The phylogeny of Myxosporea (Myxozoa) based on small subunit ribosomal RNA gene analysis. Int J Parasitol 2006; 36(14): 1521-1534. PMid:16904677. http://dx.doi.org/10.1016/j.ijpara.2006.06.016.

Gilbert MA, Granath WO Jr. Persistent infection of Myxobolus cerebralis, the causative agent of salmonid whirling disease, in Tubifex tubifex. J Parasitol 2001; 87(1): 101-107. PMid:11227872. http://dx.doi. org/10.1645/0022-3395(2001)087[0101:PIOMCT]2.0.CO;2.

Hall T. BioEdit: biological sequence alignment editor for Win95/98/NT/2K/ XP. Carlsbad, CA: Ibis Biosciences; 2007.

Liu XH, Zhang JY, Batueva MD, Voronin VN. Supplemental description and molecular characterization of Myxobolus miyarii Kudo, 1919 (Myxosporea: Myxobolidae) infecting intestine of Amur catfish (Silurus asotus). Parasitol Res 2016; 115(4): 1547-1556. PMid:26685700. http:// dx.doi.org/10.1007/s00436-015-4889-x.

Lom J, Diková I. Myxozoan genera: definition and notes on taxonomy, life-cycle terminology and pathogenic species. Folia Parasitol (Praha) 2006 53(1): 1-36. PMid:16696428. http://dx.doi.org/10.14411/fp.2006.001.

Luna LG. Manual of histologic staining methods of the armed forces institute of pathology. 3rd ed. New York: MacGraw-Hill Book Company; 1968. 258 p.

Martins ML, Souza VN, Moraes JRE, Moraes FR. Gill infection of Leporinus macrocephalus Garavello \& Britski, 1988 (Osteichthyes: Anostomidae) by Henneguya leporinicola n. sp. (Myxozoa: Myxobolidae). Description, histopathology and treatment. Rev Bras Biol 1999; 59(3): 527-534. PMid:10765464. http://dx.doi.org/10.1590/S0034-71081999000300018.

Masoumian M, Baska F, Molnár K. Myxobolus nodulointestinalis sp. n. (Myxosporea, Myxobolidae), a parasite of the intestine of Barbus sharpeyi. Dis Aquat Organ 1996; 24: 35-39. http://dx.doi.org/10.3354/dao024035.

Mathews PD, Maia AAM, Adriano EA. Morphological and ultrastructural aspects of Myxobolus niger n. sp. (Myxozoa) gill parasite of Corydoras melini (Siluriformes: Callichthyidae) from Brazilian Amazon. Acta Trop 2016; 158: 214-219. PMid:26992296. http://dx.doi.org/10.1016/j. actatropica.2016.03.016.

Matos E, Tajdari J, Azevedo C. Ultrastructural studies of Henneguya rhamdia n. sp. (Myxozoa) a parasite from the Amazon Teleost fish Rhamdia quelen (Pimelodidae). J Eukaryot Microbiol 2005; 52(6): 532-537. PMid:16313446. http://dx.doi.org/10.1111/j.1550-7408.2005.00063.x.

Molnár K. Redescription and Histopathology of Myxobolus cyprinicola Reuss, 1906, an intestinal parasite of the common carp (Cyprinus carpio L.). Acta Protozool 2002; 41: 279-283.

Molnár K, Marton S, Eszterbauer E, Székely C. Description of Myxobolus gayerae sp. n. and re-description of M. leuciscini infecting European chub 
from the Hungarian stretch of the river Danube. Dis Aquat Organ 2007; 78(2): 147-153. PMid:18286811. http://dx.doi.org/10.3354/dao01854.

Molnár K, Székely C, Mohamed K, Shaharom-harrison F. Myxozoan pathogens in cultured Malaysian fishes. I. Myxozoan infections of the sutchi catfish Pangasius hypophthalmus in freshwater cage cultures. Dis Aquat Organ 2006; 68(3): 209-218. PMid:16610586. http://dx.doi. org/10.3354/dao068209.

Moreira GSA, Adriano EA, Silva MRM, Ceccarelli PS, Maia AAM. The morphological and molecular characterization of Henneguya rotunda n. sp., a parasite of the gill arch and fins of Salminus brasiliensis from the Mogi Guaçu River, Brazil. Parasitol Res 2014; 113(5): 1703-1711. PMid:24535737. http://dx.doi.org/10.1007/s00436-014-3815-y.

Narasimhamurti CC, Kalavati C. A NEW Myxosporidian, Myxobolus bivacuolatus $n . s p$. Parasitic in the Intestinal Wall of the Fresh Water Fish, Clarius batrachus. Arch Protistenkd 1986; 131(1-2): 153-157. http:// dx.doi.org/10.1016/S0003-9365(86)80073-2.
Penido JCN. Quelques nouvelles Myxosporidies parasites de poissons d'eau douce du Brésil. In: Societé de Biologie, editor. Comptes Rendus Hebdomadaires des Séances et memoires. Paris: G. Masson; 1927. p. 850-852.

Rambaut A, Suchard M, Drummond A. Tracer v1.4.1 [online]. 2008 [cited 2017 August 25]. Available from: http://tree.bio.ed.ac.uk/software/tracer

Rocha S, Casal G, Matos E, Matos P, Silva JM, Alves A, et al. Morphological and molecular characterization of a myxosporean parasite infecting the skeletal musculature of an ornamental fish species from the Amazon River. Microsc Microanal2016; 22(S4): 24-25. http://dx.doi.org/10.1017/ S1431927616000313.

Ronquist F, Huelsenbeck JP. MrBayes 3: Bayesian phylogenetic inference under mixed models. Bioinformatics 2003; 19(12): 1572-1574. PMid:12912839. http://dx.doi.org/10.1093/bioinformatics/btg180.

Swofford DL. PAUP* Phylogenetic Analysis Using Parsimony (*and other methods). Version 4. Sunderland: Sinauer Associates; 1998. 128 p. 